\title{
Far from a Burden: EU Migrants as Pioneers of a European Social Protection System from below
}

\author{
Dr Marie Godin (University of Oxford) \\ International Migration \\ First published online 10 October 2019 \\ https://onlinelibrary.wiley.com/doi/abs/10.1111/imig.12651
}

\begin{abstract}
At a time when the belief in a welfare crisis is being connected to a so-called "migration crisis", in particular in the United Kingdom, it is important to look at the lived experiences of mobile EU citizens and the influence of transnational social protection practices. The article introduces the concept of a "migration-welfare corridor" - as opposed to the widespread welfare magnet hypothesis - taking into consideration the role of welfare systems in origin and destination countries at different stages of a migrant's life cycle, the changing nature of the welfare habitus as well as migrants' attitudes towards what can be defined as welfare chauvinism. Looking specifically at the case of Spanish and Polish migrants in the UK who have reacted to this protracted environment of deterrence, particularly in respect to their welfare rights, this paper discusses several dimensions that should be taken into consideration when analyzing transnational social protection practices from below.
\end{abstract}

\section{INTRODUCTION}

The notion that European migrants rely heavily on the national welfare state of their host country has recently become widespread in the media and in public opinion. As a consequence of this, freedom of movement within the EU is increasingly becoming questioned. The Brexit campaign was a case in point because it was mainly supported by the (distorted) idea that EU migrants (and in particular East Europeans migrants) are not only coming to "steal jobs" but also are attracted by more generous welfare benefits. The post-Brexit political context has continued around the same lines as illustrated by the following headline "Theresa May will use Brexit to stop EU migrants claiming UK benefits" published on 2 January 2017 in The Independent (Fenton, 2017). In that regard, the idea of "welfare shopping" has become one of the main arguments used by anti-European populist groups to attract voters. As a response to reduce this so-called benefit tourism - for which in fact little evidence exists (McInnes, 2014) - several EU countries have been introducing a new range of social policies to control 
immigrant access to domestic welfare, such as the UK imposing a "right to reside" test on EU nationals "habitually resident" before they can claim social benefits (Travis, 2018).

It seems therefore that the only acceptable EU migrant is the "worker citizen" (Anderson, 2015), whose skills are valued in the labour market and who at the same time represent a low risk in terms of using the national welfare state. In this growing "hostile environment policy" put in place by Theresa May when she was Home Secretary, one may wonder how EU migrants overcome growing limitations concerning access to their social rights in a context where access to formal social protection in their country of residence is drastically reducing. In a post-referendum Brexit context, EU citizens who wish to apply for a permanent residency - so as to secure their legal status - must prove having had a Comprehensive Sickness Insurance (CSI) valid for five years. The logic underlying this requirement is to bring the proof that EU citizen were at any point - not even "potentially" - a burden for the UK welfare state system. In fact, the simple fact that a EU citizens might have been at some point in their life trajectory a potential user of the welfare state system is sufficient to make them fall into the category of the "bad" migrant or "welfare scrounger" (Anderson, 2013).

One may wonder how EU migrants react to this deterring environment towards them, in particular in the UK context with the "hostile environment" policy towards immigrants, and in particular with respect to their social/welfare rights. The literature on welfare and migration focuses on the one hand on transnational social protection arrangements and migration (i.e. Bilecen and Barglowski, 2015; Levitt et al., 2017) with a specific focus on South-North migration and migrant ways of responding to the vulnerability of their left-behind families and communities, and indirectly to their own vulnerability (Boccagni, 2015). On the other hand, a majority of studies investigate the link between attitudes towards the welfare state, immigration and migrants both in the European context (Senik et al., 2008) as well as in the United States (Garand et al., 2017), but essentially from the "natives' perspective". In fact, both bodies of literature have overlooked the lived experiences of EU mobile citizens at this particular point in time - a historical moment that combines different types of "crisis" (crisis of the welfare state, an economic crisis, a so-called "refugee crisis" and the Brexit crisis), and in particular, how they arrange their social protection across borders, both formally and informally. This article will look specifically at the case of Spanish and Polish migrants residing in the UK before and after the Brexit referendum took place. 


\section{FILLING THE GAPS IN THE LITERATURE ON WELFARE AND MIGRATION IN EUROPE}

Many studies which focus on the topic of welfare and migration in Western countries are testing the "welfare magnet hypothesis" (Borjas, 1999), which postulates that poorer migrants will be more likely to cluster in more generous welfare states. This hypothesis was first tested in the US context (Giulietti, 2014) and more recently in Europe with mostly inconclusive results (De Giorgi and Pellizzari, 2009; Geddes and Hadj-Abdou, 2016). More importantly, this hypothesis implies four main biases when considering social protection and migration in the EU context.

Firstly, research on welfare systems and migration within the EU has mainly focused on Central and Eastern European migrants, thereby creating an "East-West bias". This "geographical and racialized bias" has led to a lack of a comparative perspective among EU migrant groups, as well as between non-EU and EU migrants. However, a new range of studies have embarked on less orthodox comparisons, such as Jendrissek's (2014) research on young, well-qualified Poles and Spaniards in the UK context, and the study by Bygnes and Erdal (2017) comparing the same groups but in the Norwegian context. My paper also builds on this new corpus of research.

Secondly, research on welfare states and migration in the EU focuses mainly on the country of destination ("a receiving country bias"), with migrants moving from a supposedly "weak welfare state" to a "strong welfare state". This has resulted in neglect of the important role of welfare systems in origin countries on migration aspirations and decisions, as well as on transnational social protection arrangements before and after migration took place for both migrants and non-migrants.

Thirdly, there is often an underlying assumption that migrants represent a homogenous category ("homogeneity bias"). But depending on the life-stage migrants are in, they typically have different social needs, as do their family members. A life-course approach is often absent in the literature on social protection and migration, which tends to focus on one category of migrants. Few studies examine changes in terms of migrants' social needs or compare different national groups of migrants in similar phases of their life-course, which in fact may reveal similar patterns in terms of social protection arrangements. 
Lastly, the dialectic between transnational informal and formal social protection mechanisms is absent in the dominant literature on welfare and migration which, as stressed above, mainly focuses on testing the welfare magnet and welfare dependency hypotheses. Therefore, the predominant focus has been not only on the destination country but also on the formal features of social protection. Furthermore, a narrow definition of informal social protection mechanisms can be found, limited to the destination country and mainly provided by family members and local networks. As an example, the seminal book by Sabates-Wheeler and Feldman (2011) identifies four components of social protection for international migrants to consider: access, portability, labour market conditions, and access to informal networks to support migrants and their family members in the country of destination. The transnational migration scholarship on social protection has challenged this vision by looking at the intersections between formal, informal and semi-formal social protection mechanisms across borders for mobile populations embedded in immobile welfare systems (Bilecen and Barglowski, 2015; Serra Mingot and Mazzucato, 2017). A characteristic feature of migrants from the 'Global South', and in particular migrants moving from low-income to high-income countries, is to address transnational needs through migration (Boccagni, 2017). However, there is still very little in the academic literature on EU migrants, transnationalism and both formal and informal social protection. When looking at EU migrants, migration scholars often reproduce what can be defined as a "welfare nationalist/Europeanist bias", focusing mainly on the formal aspects of social protection in destination countries (Bruzelius et al., 2017). As will be shown, not only do EU migrants rely on informal structures of social protection in their destination country, but they also develop transnational welfare strategies implicating the country of destination and/or the country of origin in different ways and weights.

\section{A BOTTOM-UP APPROACH FOR CAPTURING TRANSNATIONAL WELFARE ARRANGEMENTS}

Providing social protection for their citizens has been one of the main ambitions of European welfare states (Esping-Andersen, 1990). However, the welfare regimes have been strongly connected with the nation state, in which provisions are still predominantly linked to nationality and residency. This is reflected in the classic distinctions that are made of welfare state types across Europe (Esping-Andersen, 1990). The triad 'family-market-state' is used in order to distinguish between different types of welfare provision. With the growing number of people embedded in "transnational social fields", scholars in the field have been calling to move 
beyond classic, state-based approaches and to consider social protection across borders with states and non-states providing for them. As a result, several conceptual frameworks have started to emerge in the field, such as the one of "resources environment" as described by Levitt et al. (2017) which includes: the role of states in providing social protection, the market, the third sector actor, and social protection provided by individuals' personal networks in both destination and origin countries. In the case of EU migrants, and in particular since they are entitled to freedom of movement, their "resource environment" often encompasses a set of transnational social protection opportunities that can be mobilized to address in specific ways their social needs, and the needs of those living with them and those "left behind".

The idea that contemporary welfare states are in crisis is far from new and has been talked about since the early 1980s (Joppke, 1987). In that context, the provision of social protection for migrants in welfare states has always been a contentious issue (Faist, 2017). Therefore, my empirical results provide some new elements on how EU migrants organize their social protection across borders, often being aware of this contentious issue. Often forgotten in this dominant narrative is the fact noted by Righard (2008) that migrants arrive in the host society with a "welfare repertoire" on their own, which in varying degrees challenges and is challenged by the host society's standardized "resource environment" as well as the existing exclusionary/inclusionary measures towards migrants' social protection. As a result, migrants may develop transnational social protection strategies to not only provide for those left-behind but also to resist some of the constraints such as the ones related to natives' attitudes towards migrants' access to welfare services. The literature on welfare and migration tends to be focused after migration has taken place and leaves understudied the role of "welfare repertoires" in the origin country affecting migrants' decisions over particular "welfare dilemmas" they might have for themselves and their family, and which may change over time and space across the life-course. In that regard, Sen's (1985) "set of capabilities" approach provides an original conceptual framework to better seize migrants' agencies in a contentious political environment.

As highlighted by Deneulin and McGregor (2010), the notion of capability is closely related to Sen's conception of freedom, which he defines as "the real opportunity that we have to accomplish what we value" (1985: 31). The capability approach specifies an "evaluative space" (Robeyns, 2006) allowing us to focus on the agency that migrants exercise across borders and which is based on a certain "social conception of wellbeing" (Deneulin and 
McGregor, 2010: 504) - in this particular case, a certain social conception of welfare. The changing nature of transnational welfare repertoires across time and space as well as migrants' attitudes towards welfare chauvinism (Keskinen et al., 2016) are two dimensions that need to be taken into consideration when capturing some of the current dynamics towards EU citizens and transnational social protection from below. These two discussions are often overlooked in the literature on welfare and migration within the EU. This will now be discussed based on my case study of Spanish and Polish migrants in the UK.

\section{POLISH AND SPANISH MIGRANTS IN THE UK CONTEXT}

Polish migrants now represent the largest EU migrant group in the UK. In 2017, Poland was the most common non-UK country of birth and Polish was the most common non-British nationality in the UK with an estimated 1 million Polish nationals (ONS, 2017). EU migrants from Central and Eastern European (CEE) countries who decided to migrate after the EU enlargements of 2004 and 2007 have often been regarded mainly as labour migrants and in particular as lower-skilled workers. However, new studies have been showing that noneconomic reasons, which include lifestyle issues, quality of life and social networks, are also factors that explain Polish (and other CEE) migration (Bivand Erdal and Lewicki, 2016; Grabowska and Garapich, 2016). The UK tabloids have been particularly abusive towards Polish migrants (and CEE migrants more generally), accusing them of abusing the British welfare system and having only migrated for that particular purpose. It has also become a salient issue in UK politics, with politicians playing this "sponger welfare card" for electoral purposes, especially during the Brexit referendum and by the "Leave" campaign.

Concerning Spanish migrants, the Office for National Statistics estimated that there were 116,000 Spanish citizens living in the UK in December 2015, with 92 per cent living in England and 6 per cent in Scotland. It is often argued that the 2008 economic crisis led to new migration patterns from Southern European countries towards countries that were less affected by the global economic crisis, such as the United Kingdom (Bygnes, 2017). In regard to Spain, while the country had become a country of net immigration since the mid-1970s, by 2010 as a result of the economic crisis, the migratory balance had turned negative once again, both as a result of reduced immigration and increased emigration. Bermudez and Brey (2017) have argued that this change has been due to return migration from those who had previously migrated to Spain from Latin America, as well as a long-lasting emigration of young, qualified natives towards European countries in search of new experiences or as part of a globalizing 
labour force. However, this "new" emigration flow of young Spaniards to the UK cannot be understood only as a direct result of the economic crisis. They seem to be more diverse than often portrayed by the official discourse. Onward migration flows within the EU from Spain, as well as the migration of both low- and high-skilled natives, young and old people, are still under-studied.

The distinction in the literature between "labour migration" versus "lifestyle migration" has become more and more contestable with the complexity of the decision-making process going far beyond the divide between a search for better financial gratification and a finer lifestyle (see for example Bivand Erdal and Lewicki, 2016; Grabowska and Garapich, 2016). Studies on intra-European migration show the diverse motivations of people moving for a better quality of life, to study abroad, family reasons or simply for love (e.g. King, 2002; King and Ruiz-Gelices, 2003; Benson and O'Reilly, 2009; Recchi and Favell, 2009). In this study, Spanish and Polish migrants were often driven by mixed rationales entangling both economic and lifestyle components.

My focus on these two groups of EU migrants (Polish and Spanish) in the UK defines different types of "transnational welfare corridors". There is an extensive literature on welfare model classification inspired by Esping-Andersen's typology (1990). In that typology, Southern European as well as Central and Eastern European welfare systems were initially absent. Until now, many discussions have existed on whether new welfare types should be created (or hybrid welfare types) or if those systems should be integrated into the existing typology. It is beyond the scope of this article to discuss this literature. However, the triangulation between family-market-welfare states is clearly one that is perceived to be relevant by EU migrants because they often engage in "welfare repertoires" comparison exercises, looking at both the destination and origin countries' legal, social, cultural and economic dimensions before making decisions about their own welfare and that of their family. With accessing welfare services for migrants in the UK becoming such a contentious issue over time, and in particular since the increasingly visible hostile environment, the political context has also started to play a role in migrants' decisions about social protection arrangements.

My analysis in this paper draws from semi-structured in-depth interviews collected between March 2016 and January 2017. The research was thus conducted both before and after the Brexit referendum of 23 June 2016 and is part of the "mobilewelfare project". ${ }^{1}$ In this article I only consider the data collected in the UK, which comprises 12 interviews with Polish 
migrants, and 12 with Spanish migrants. The selection of interviewees was done through snowball sampling methods with multiple entry points in order to ensure diversified coverage of the different participant profiles, especially in terms of socio-economic background. Besides the migration experience, the sampling targeted men and women currently active in the labour market - employed or unemployed - or who were active in the past. Additionally, different life transition events were taken into consideration to diversify the sample in terms of sex, age, family situation and occupational situation. Therefore, Polish and Spanish migrants and returnees interviewed were at different life-stages, mainly either young professionals, with a family or retired/almost retired.

\section{BEYOND THE DOMINANT WELFARE-MAGNET NARRATIVE}

The "welfare-magnet hypothesis" (Borjas, 1999) in the field of migration and welfare has generally been considered from the perspective of the destination country as a "pull-factor" and in the country of origin as a "push-factor". In that perspective, migrants from low-income countries with weak welfare systems are attracted to high-income countries with a stronger welfare system. In addition, the magnet hypothesis often assumes that migrants have a sufficient knowledge of the welfare system both of their country of origin and of their potential country of destination, and those migrants can compare the generosity of different welfare systems before making a genuine decision to migrate. And yet, in my study, the interviewees never mentioned the supposedly strong welfare system in the country of destination as one of the driving factors to migrate. In all cases, my interviews show that, for the majority, their knowledge of the formal welfare system in the destination country was almost non-existent, or irrelevant in cases where people had some knowledge before migration took place. Furthermore, many were unaware of the social rights they might lose in their origin country by moving. In many cases, Polish and Spanish migrants came as "free-movers" rather than “immigrants” (Favell, 2008: 708):

I didn't get a lot of support from my parents or my friends. People thought I was a little bit crazy and there was no need for me to do all that. But in my eyes I grew up knowing that I wanted to live outside Spain. I was 27 already; I didn't have a partner or a relationship so I thought if I don't do this now, I will never do it. So it was little bit like I thought "just go for it" and I didn't give it a lot of thought. I thought if you think too much about it, you won't do anything [...] I had accommodation from my first night and for the next 2-3 months [...] That was probably what made me come without thinking too much about the consequences. [Spanish migrant living in London since 2001] 
However, the capability to rely on welfare resources back home, for both Polish and Spanish migrants, has played an important role in the actual decision to move. In the majority of cases, the family in the country of origin often guarantees this cushioning role, which is often needed when one is moving from one country to another, either in supporting the migrant abroad or in helping him/her back upon a possible return. Therefore, several accounts show that Spanish and Polish intra-EU movers indeed take specific characteristics of their welfare "resource environment" (Levitt et al., 2017) into account when making migration decisions, but not necessarily those of the receiving state - as described in the welfare magnet hypothesis - but rather of the country of origin. It is the "capacity" to return home where migrants have a strong family welfare support which has influenced their actual decision to migrate.

I mean I wouldn't be here if it wasn't for them [talking about his parents]. Initially it was my parents who wanted to give me 400 euros to come here, so no. I wouldn't be the person I am today without them. [Spanish migrant living in London since 2000]

If anything, they were supporting me over the years, when I was still a student, so they would actually send me money over here, for me to spend. So, I'd get an allowance from them whenever the times were rough. But I used to work throughout both of my degrees - so that combined with a maintenance loan and grant that I actually got. [Polish migrant living in Oxford, in the UK since 2007]

This "latent transnational social safety net" often plays a prominent role during the first phase of the migration process and then tends to weaken over time. In some cases, it has remained important over the years. If some migrants have gained the right to rely on social benefits (such as in the case of unemployment), some perceive this formal support as insufficient - especially in the London/UK context - stating the need to combine this formal social benefit support with some informal support from back home (through cash-transfers). It is this transnational intermingling of both welfare systems (state and family-private sector) in the country of origin and destination that is often overlooked in the literature. This criss-cross between welfare systems creates specific "transnational welfare repertoires" upon which migrants as well as non-migrants can exercise their agencies.

The welfare magnet hypothesis that has been extensively used and tested in the field of migration and social protection, in particular in the Global North, often implies the existence of a preferred direction of magnetization, from the country of origin to the country of 
destination. The possibility of having not only different types of social protection remittances sent back home but also reversely (also called "reverse remittances"; Mazzucato, 2011) is hardly ever mentioned. Therefore, the dynamic and complex social protection arrangements linking the country of origin and destination (in all aspects: formal, informal and semi-formal) can be better understood through the concept of a "welfare-elasticity corridor" in which the two poles, the country of origin and the country of destination, may play a changing role across the life-course. Distinct from the idea of unidirectionality which is often attached to the welfare magnet hypothesis, the notion of "elasticity" between the two poles reflects more accurately migrants' transnational social protection configurations. The elasticity of transnational social protection arrangements often varies across time and space depending on the migrants' as well as non-migrants' social needs, the growing knowledge of the welfare system in the destination county and the acquisition of certain social rights over time, and the socio-economic status of both migrants as well as the non-migrants. The following quote by a Polish woman who came to the UK in 2005 after having lived in France for a few years illustrates this notion of "welfareelasticity corridor". She explained to me how they managed to make the UK their home and start a family with some support from her sister who came to join them a bit later from Poland. While they were initially supporting her back home, by moving to the UK, the sister started to support them by providing them with informal childcare support:

Yes she came to us and said I'm fed up with Poland, I want to start something different [...] She came for a few months and stayed with us. Then she found a job and she has her own family as well, she's quite happy. She lives 15 minutes walk from us, our houses are very close and, that's a help. She helped me when I was working... She looked after my daughter for one day as she worked part time. [Polish migrant, living in London since 2005]

In the above case, not only has the directionality of social protection transfers changed but also the type of social protection support. The next example illustrates this elasticity within a transnational welfare corridor that fluctuates over time and shows the importance of considering a family life-course perspective. One of our Polish interviewees in his twenties and living in Oxford explained to us that his father first migrated to the Netherlands to work as a butcher in the late 1980s. During that period (more than ten years), he supported his family financially, covering for their social protection needs (especially concerning access to formal education as well as healthcare), and moving back and forth between the two countries. In 2012, after having finished his studies, the interviewee migrated to the UK with his fiancée. 
They both managed to migrate, having received the financial support of his family back home. Nowadays, his father is back in Poland where he has now transferred his state pension from the Netherlands, as the costs of living are lower in Poland. For the moment, "no one needs help from anyone", he pointed out to me during the interview. However, thinking about the near future, he considers the possibility to send his wife and future children back home to Poland, as they will be better off than in the UK where they do not have family support. Having compared childcare support systems in Poland and the UK, he believes that having the support of his family back home will be better. The new Polish scheme for child benefits, designed by the Polish authorities ( $£ 87$ per month child benefit plan) to increase the number of children as well as an incentive for people to stay/or return in the country, was also discussed during the interview, being considered as a potential incentive to return home to bring up his children.

This account indicates multiple changes in terms of the directionality, intensity and nature of transnational social protection assemblages. The concept of "welfare elasticity corridor" allows considering a "linked-lives perspective" (Findlay et al., 2015) that recognizes mobility as relational either within a household moving together and/or between movers and non-movers all being embedded in a changing transnational welfare resource environment (Levitt et al., 2017).

\section{TRANSNATIONAL LEGAL CONSCIOUSNESS AND ATTITUDES TOWARDS SOCIAL RIGHTS BY EU MIGRANTS}

Having the right "to use the system" is in fact very different than making the decision to use that right (see Sen, 1985). Coldron and Ackers (2009) looked at the agency of EU retired migrants for the welfare systems of receiving regions and have identified three types of agency in terms of how migrants rely on and use social rights: 1) the exercise of rights; (2) the manipulation of rights; and (3) the abuse of rights.

This typology is quite normative and also limited, as it does not encompass migrants' agencies being embedded in transnational welfare resources environments. In the literature, it is often reported that EU migrants refrain from using their right to social protection in their chosen destination country either due to lack of knowledge of their social rights or for fear of losing their right to residence (Lafleur and Stanek, 2017). This is often partly due to migrants' unfamiliarity with the local system and the systemic differences between the sending and the 
receiving countries (“different types of welfare repertoires"). This particular lack of agency may partly explain why some Polish and Spanish migrants living in the UK end up by not mobilizing their social rights. Therefore, my findings suggest to refine Coldron and Ackers' (2009) typology, in that it reproduces in many ways some of the biases highlighted earlier in the article (a "receiving country bias", a "geographical and racialised bias", an "homogeneity bias" and a "welfare nationalist/Europeanist bias").

For instance, the majority of the Spanish and Polish interviewees living in the UK are regularly returning back home to visit their parents and family members. At the same time, they often seize the opportunity to fulfil some of their social needs, especially in relation to their health. Here is an illustrative example about relying on private healthcare in the country of origin:

Before I came I didn't have any knowledge, so I can't really rely on that. My experience of the system over here... probably a bit disappointing, because I found that the healthcare system isn't better than back home. What I have found is that private healthcare is disproportionately more expensive than back home, in comparison [...] Three years ago, I had an injury on my Achilles, just from sports. I went to a GP over here, and I just got some painkillers, so after two weeks, nothing was happening, and they wouldn't really refer me to a specialist $[\ldots]$ So in the end I actually bought tickets home, went to a private hospital in Warsaw, got everything done in two days, and it probably cost me half [of what it would have cost here]. Same with dental care, I suppose. Every time I go back, I do the same thing, I just go to the same dentist. [Polish migrant living in Oxford, in the UK since 2007]

This extract shows how the issue of trust in the local health system is paramount in explaining why people choose to avoid the public welfare system in the UK and prefer to pay to return home. EU migrants often express their preference for a place where people have known them for some time and have monitored them before they decided to migrate. Even though it is not a necessity to do it, they like being checked by those who they trust and who are familiar to them. These welfare mobility strategies - and in particular in the field of health - are quite common. In reality, welfare repertoires do not change that easily and rapidly. In the following extract, not only are family members going to Spain to have their medical checks; this welfare mobility strategy is also being used as a way to put pressure on the National Health Service (NHS) in the UK. In getting a medical diagnosis from the country of origin (based on a private insurance she kept since she left), Alessia (from Spain) has hoped to accelerate the medical process in the country of destination. Welfare-related mobility is used here not only because of 
a lack of trust in the system but as a leveraging strategy to put pressure on the welfare state system in the country of destination.

Yes, I cannot use the Spanish public healthcare system because you have to be registered there to be able to go. So, I haven't got access to it, unless there's an emergency, which we have had as well, where we've gone to the hospital. But, I have a private insurance. So, we go and use that when we are there. There's no questions asked. You don't have to go to a GP or anything. You've got a card and you make an appointment, end of story [...] It's also for the children. It's been for my husband as well, he's also had things... We had to go to Spain to find out what the problem was because we couldn't find out here. Yes it was the only way to move things forward, and I had this with my daughter as well. It's the only way to force their hand and say "yeah this is what's wrong with me, and this is the diagnostic", otherwise they don't listen to you. [Alessia from Spain, living in the UK since 2004]

In this case, Alessia compares her situation with the one she used to have before migrating. While migration has been seen as an opportunity to advance one's life, it has also been perceived as a disruptive force concerning social protection before and after migrating. Returning back home for shorter periods of time allows the migrant and her or his family to counteract this perceived social welfare deprivation. This example reveals a specific type of transnational legal consciousness that is not only about exercising its rights and/or manipulating these rights in the country of destination, but is also about "maximizing those rights" in adopting a transnational and comparative attitude and making the most of the welfare environment in increasing one's own leverage.

But the stigmatization of migrants as potential users of welfare resources in the country of destination has sometimes led them to develop "strategies of avoidance" (Goffman, 1967). In the UK, the public discourse on the welfare-migration crisis has centred mainly on the negative impact of migrants on the country's public services. The majority of my interviewees mentioned that they are aware of their social rights, either contributory and non-contributory ones, but still deliberately chose not to use them. As mentioned by Abrego (2011: 341), "people develop stratified levels of rights awareness and pursue various conflict-resolution strategies... and generally interpret their lives in different ways". Ewick and Silbey (1998) identify different types of legal consciousness with people who either are "with the law", find it to be accessible, utilize it as a resource and perceive it as a game; or who are "against the law", trapped by its pervasive authority and are not likely to make any claims (1998: 48). My empirical data reveal other types of legal consciousness towards this complex nesting of social rights (Faist, 2001). 
The Polish and Spanish migrants in my sample were all in a situation of being "with the law", meaning that they all had a legal right to stay in the UK. But even when entitled, and in particular for the Polish migrants interviewed, they said that they tend not to rely on the welfare state system in their place of residence, not because they do not have a legal consciousness of being "with the law", but due to a feeling of shame attached to the idea of being dependent on the system. Some of them have therefore opted to minimize their use of rights by relying either on private services or on informal welfare providers in the place of residence and/or back home. Many of them have in fact internalized this negative public discourse targeted against migrants - and in particular East European migrants - and the welfare state system. Those with enough economic resources can choose to escape the dominant narrative that draws the line between "the good" and "the bad" migrants, the deserving ones and the undeserving ones, thereby giving support to the ideas underlying the welfare magnet hypothesis. For instance, Pamela made it clear during the interview that she will go back to Spain if she became unemployed:

(...) regarding unemployment I have always said the moment I have to get the unemployment benefit here in London because I can't find anything I'll go back to Spain, I rather go back to Spain, than getting the unemployment benefit here. (...) I don't think it's ethical, I mean, because there are a lot of Spanish, let's say immigrants that come here and directly what they do is get the unemployment benefit, here, it's like, what are you doing? [Pamela from Spain, in the UK since 2007]

To counteract such negative discourses, migrants develop "a feeling of pride" of staying independent of the welfare state system in their country of residence. Paradoxically, in doing so, they also strengthen the negative narrative targeting the "others", the "immoral migrants" whom they often socially distant themselves from.

I don't know, I haven't really used any benefits apart from the one they offer just after they are born, the child benefit. That's the only one. [...] I have never lost a job, I've never had a break. Obviously, it would help me if I lost my job; I would go to a job centre.... Actually I don't know if I would. I would just keep looking for work. [...] I know that there are people who use the system wrongly and I worry that I would be put in the same bag. I am completely not using it that way. I know some people need it, they are disabled or a single mum, there are lots of situations where you need government help but there are lots of people abusing the system. There are not really people checking them. [Polish migrant in London, since 1998].

Not only do public attitudes towards migrants in terms of welfare resources affect the way some migrants decide to rely or not on the system. Different types of "transnational legal 
consciousness" in relation to social protection explain some of the mixed-mobilities strategies that both migrants and non-migrants engage in, revealing different types of "welfare careers" that are either more or less "mobile" or more or less "sedentary" (Boccagni, 2015).

\section{CONCLUSION}

Whilst the politicization of migration has been become a hot issue in the UK, particularly since the EU's eastern enlargement, the principle of freedom of movement has been called into question in several EU countries; this is particularly so since the 2008 economic crisis and the more recent so-called "refugee crisis". This article has first discussed the welfare magnet hypothesis to address some of its shortcomings. So far, the body of literature on migration and social protection within a European context has overlooked the increasing role of "transnational social protection assemblages" (Faist, 2013) for EU mobile citizens in times of crisis. In fact, little is still known about the lived experiences of EU mobile citizens in tackling social risks and vulnerabilities.

Migration scholarship, in particular when looking at EU migrants, still suffers from methodological nationalism (Wimmer and Glick Schiller, 2002), privileging one national welfare state approach - very often the destination country as the main and most legitimate provider of social protection. In relying on the "capability approach" as applied as an evaluative frame to understand social protection and migration in a European context, this article accounts for the diversity of complex patterns of transnational social protection arrangements across borders among different profiles of Spanish and Polish migrants. With EU mobility as a fundamental right to EU citizens, migrants have been organizing and reorganizing through the life-course their social protection across territories far beyond the old notion of the welfare state as the main legitimate provider of social protection. Complex social protection processes have been taking place across territories, combining different kinds of providers of social protection (formal, informal and semi-formal) with migrants and non-migrants moving from receivers to providers of social protection across the life-course. Based on empirical cases, the useful concept of the "welfare elasticity corridor" was put forward, which aims to go beyond notions of unilateral welfare magnet effects, but combines the two poles - country of origin and country of destination - taking into account the issue of temporality (life-course) and spatiality (different territories). This encapsulates better the role played by the welfare resource environment in the country of origin with the family back home playing the role of a latent 
transnational social safety net that would enable migrants to move back if things did not go as planned.

Secondly, a large part of the literature on migration and welfare focuses on natives' attitudes towards migrants and immigration in relation to the welfare state. Those studies are mostly of a quantitative nature and investigate mainly the natives' point of view. On the other hand, migrants' reactions towards these attitudes, and the impact they may have on the way they organize their social protection, are often overlooked. In times where the perception of a welfare state crisis is often being connected to the so-called migration crisis, it is important to look at how migrants position themselves towards such anti-migration discourses, and how this may directly or indirectly impact on their own social practices in terms of transnational social protection across borders. As described, a series of multiple assessments are being made consecutively or simultaneously by Polish and Spanish migrants, relying on their right to freedom of movement, increasing the spectrum of what is possible to achieve, what targets people choose to achieve, and how to achieve them.

In a post-Brexit context, exercising Treaty rights has become more than uncertain. As a result, new uncertainties have emerged that will have multiple potential impacts on the way that migrants and non-migrants will have to organize their social protection across borders, either transnationally or nationally. Ironically, changes in mobility rights in a post-Brexit context might even generate a form of "involuntary dependency" on the British welfare system by EU migrants. This paradoxical self-fulfilling prophecy may be one (among many others) unexpected consequence of Brexit.

\footnotetext{
${ }^{1}$ The mobilewelfare project is a comparative empirical study taking place in several European countries in order to improve the theorization of the role of welfare provisions in migration aspirations and decisions, looking at both EU and non-EU migrants. The overall study targets migrants, returnees and non-migrants in five EU member states (the Netherlands, Poland, Portugal, Spain and the UK) as well as two additional countries, Norway and Turkey. The selection of countries was made in order to cover a plurality of types of welfare system.
} 


\section{REFERENCES}

Abrego, L.J. 2011. "Legal consciousness of undocumented Latinos: fear and stigma as barriers to claims-making for first- and 1.5-generation immigrants", Law and Society Review, 45(2): 337370.

Anderson, B. 2013 Us and Them? The Dangerous Politics of Immigration Controls, Oxford University Press, Oxford.

Anderson, B. 2015 "Heads I Win. Tails you Lose": Migration and the worker citizen, Current Legal Problems, 68(1): 179-196.

Benson, M., and K. O'Reilly (eds.). 2009. Lifestyle Migration: Expectations, Aspirations and Experiences. Routledge, Abingdon.

Bermudez, A. and Brey, E. 2017. "Is Spain becoming a country of emigration again? Data evidence and policy reposnses," In Lafleur, J.M. and Stanek, M. (eds) South-North Migration of EU Citizens in Times of Crisis. SpringerOpen: 83-98.

Bilecen, B., and Barglowski, K. 2015. "On the assemblages of informal and formal transnational social protection", Population, Space and Place, 21(3): 203-214.

Bivand Erdal, M. and Lewicki, A. 2016. "Polish migration within Europe: mobility, transnationalism and integration", Social Identities, 22(1): 1-9.

Boccagni, P. 2015. "Burden, blessing or both? On the mixed role of transnational ties in migrant informal social support", International Sociology, 30(3): 250-268

Boccagni, P. 2017. "Addressing transnational needs through migration? An inquiry into the reach and consequences of migrants' social protection across borders", Global Social Policy, 17(2):168187.

Borjas, G. J. 1999. "Immigration and welfare magnets", Journal of Labor Economics, 17(4): 607-637. 
Bruzelius, C., Reinprecht, C., Seeleib-Kaiser, M. 2017. "Stratified social rights limiting EU citizenship”, Journal of Common Market Studies, 55(6): 1239-1253.

Bygnes, S. 2017. "Are they leaving because of the crisis? The sociological significance of anomie as a motivation for migration", Sociology, 51(2): 258-273.

Bygnes, S. and Bivand Erdal, M. 2017. "Liquid migration, grounded lives: considerations about future mobility and settlement among Polish and Spanish migrants in Norway", Journal of Ethnic and Migration Studies, 43(1): 102-118.

Coldron, K. and L. Ackers. 2009. "European citizenship, individual agency and the challenge to social welfare systems: a case study of retirement migration in the European Union", Policy \& Politics, 37(4): 573-589.

Deneulin, S., and McGregor, J. A. 2010. "The capability approach and the politics of a social conception of wellbeing". European Journal of Social Theory, 13(4): 501-519.

De Giorgi, G. and Pellizzari, M. 2009. "Welfare migration in Europe". Labour Economics, 16(4), 353363.

Esping-Andersen, G. 1990. The Three Worlds of Welfare Capitalism. Polity, Cambridge.

Ewick, P. and Silbey, S.S. 1998. The Common Place of Law: Stories from Everyday Life, Chicago Series in Law and Society, University of Chicago Press.

Faist, T. 2001. "Social citizenship in the European Union: nested membership", Journal of Common Market Studies, 39 (1): 37-58.

Faist, T. 2013. Transnational Social Protection: An Emerging Field of Study. COMCAD Arbeitspapiere, No. 113.

Faist, T. 2017. "Transnational social protection in Europe: A social inequality perspective", Oxford Development Studies, 45(1): 20-32.

Favell, A. 2008. "The new face of East-West migration in Europe", Journal of Ethnic and Migration Studies, 34(5): 701-716. 
Fenton, S. 2017. "Theresa May will 'use Brexit to stop EU migrants claiming UK Benefits"”, The Independent, 2 January 2017.

Finlay, A., McCollum, D., Coulter, R. and Gayle, V. 2015. "New mobilities across the life course: a framework for analysing demographically linked drivers of migration", Population, Space and Place, 21(4): 390-402.

Garand,J. C., Xu, P., and Davis, B. C., 2017. "Immigration attitudes and support for the welfare state in the American mass public", American Journal of Political Science, 61(1): 146-162.

Geddes, A. and Hadj-Abdou, L. 2016. "An unstable equilibrium: freedom of movement and the welfare state in the European Union”, In Freeman, G., and Mirilovic, N. (Eds) Handbook on Migration and Social Policy, Elgar Publishing, Cheltenham, 222-238.

Giulietti, C. 2014. The welfare magnet hypothesis and the welfare take-up of migrants. IZA World of Labor, 37.

Goffman, E., 1967. Interactional Ritual: Essays on Face-to-face Behavior. Anchor Books, Garden City, NY.

Grabowska, I. and Garapich, M. P. 2016. "Social remittances and intra-EU mobility: non-financial transfers between U.K. and Poland", Journal of Ethnic and Migration Studies, 43(12): 21462162.

Jendrissek, D. 2014. Narratives of Economic Migration. The Case of Young, Well-Qualified Poles and Spaniards in the UK. University of Southampton, Faculty of Humanities, Doctoral Thesis.

Joppke, C. 1987. "The crisis of the welfare state, collective consumption, and the rise of new social actors", Berkeley Journal of Sociology, 32: 237-260.

Keskinen, S., Norocel, O.C. and Jørgensen, M.B. 2016. "The politics and policies of welfare chauvinism under the economic crisis", Critical Social Policy, 36(3): 321-329.

King, R. 2002. "Towards a new map of European migration", International Journal of Population Geography, 8(2): 89-106. 
King, R., and Ruiz-Gelices, E. 2003. "International student migration and the European 'year abroad': effects on European identity and subsequent migration behaviour", International Journal of Population Geography, 9(3): 229-252.

Lafleur, J.-M., Stanek, M. (Eds.) 2017. South-North Migration of EU Citizens in Times of Crisis. IMISCOE Research Series, SpringerOpen.

Levitt, P., Viterna, J., Mueller, A. and Lloyd, C. 2017. "Transnational social protection: setting the agenda", Oxford Development Studies, 45(1): 2-19.

Mazzucato, V. 2011. Reverse remittances in the migration-development nexus: Two-way flows between Ghana and The Netherlands. Population, Space and Place, 17(5): 454-468.

McInnes, R.2014. "Statistics on migrants and benefits", House of Commons Library standard note SN06955. http://researchbriefings.parliament.uk/ ResearchBriefing/Summary/SN06955

ONS. 2017. Population of the UK country of birth and nationality 2017. Available at: https://www.ons.gov.uk/peoplepopulation and community/population and migration/international migration/bulletins/ukpopulationby countryofbirthand nationality/2017

Recchi, E., and A. Favell. (eds). 2009. Pioneers of European Integration. Citizenship and Mobility in the EU. Edward Elgar Publishing, Cheltenham.

Righard, E. 2008. The Welfare Mobility Dilemma. Transnational Strategies and National Structuring at Crossroads. School of Social Work, Lund University.

Robeyns, I. 2006. “The capability approach in practice”, Journal of Political Philosophy, 14 (3): 35176.

Senik, C., Stichnoth, H., and Van Der Straeten, K. 2008. Immigration and natives' attitudes towards the welfare state: Evidence from the European Social Survey. PSE Working Papers, no. 2008-43.

Sabates-Wheeler, R. and Feldman, R (eds) Migration and Social Protection: Claiming Social Rights beyond Borders. Palgrave Macmillan, London. 
Serra Mingot, E. and Mazzucato, V. 2017. "Mobile populations in immobile welfare systems: a typology of institutions providing social welfare and protection within a mobility framework", European Journal of Development Research, 29(4): 787-805.

Sen, A. K. 1985. Commodities and Capabilities, Elsevier Science Publishers, Oxford.

Travis, A. 2016. "UK can refuse benefits to unemployed EU migrants, judges rule. European Court of Justice rejects Commission claim that imposition of 'right to reside' test is discriminatory", The Guardian, 14 June 2016.

Wimmer, A. and Glick Schiller, N. 2002. "Methodological nationalism and beyond: nation-state building, migration and the social sciences", Global Networks, 2(4):301-334. 